\title{
Polysèmes
}

Revue d'études intertextuelles et intermédiales

16 | 2016

Traversées

\section{Music and Metaphor: Anaïs Nin's Soundtrack in The Cities of the Interior}

Métaphores musicales : la bande-son d'Anaïs Nin dans The Cities of the

Interior

Amy D. Wells

\section{OpenEdition}

\section{Journals}

Electronic version

URL: http://journals.openedition.org/polysemes/1483

DOI: 10.4000/polysemes. 1483

ISSN: 2496-4212

Publisher

SAIT

Electronic reference

Amy D. Wells, " Music and Metaphor: Anaïs Nin's Soundtrack in The Cities of the Interior ", Polysèmes

[Online], 16 | 2016, Online since 15 November 2016, connection on 01 May 2019. URL : http://

journals.openedition.org/polysemes/1483 ; DOI : 10.4000/polysemes.1483

This text was automatically generated on 1 May 2019.

Polysèmes 


\title{
Music and Metaphor: Anaïs Nin's Soundtrack in The Cities of the Interior
}

\author{
Métaphores musicales : la bande-son d'Anaïs Nin dans The Cities of the
} Interior

Amy D. Wells

1 In the late 1940s, Anaïs Nin began publishing highly autobiographical novellas characterized by what later critics such as Sharon Spencer and Karl Orend would consider "symphonic writing." They have been quick to point out how Nin's poetic prose style brought rhythm and musicality to the series of short works which is considered to function together as a roman-fleuve. But musicality is present in these works-Ladders to Fire (1946), Children of the Albatross (1947), The Four-chambered Heart (1950), Seduction of the Minotaur (1950), and A Spy in the House of Love (1954)-not only because of Nin's style, but also because of her strategic and narrative uses of musicians, musical metaphors, and even precise references to specific musical works such as César Franck's Symphony in D Minor (1888) and Claude Debussy's Isle Joyeuse (1904), and to the jazz genre. In this analysis, we will investigate the role of these musical pieces within the context of the narrative to determine how they bring a further meaning to the text based on their sounds or historical relevance, paying special attention to their relationship to the expression and representaiton of female sexuality. We will also examine Nin's use of musical metaphor to establish her "soundtrack" strategy within The Cities of the Interior: the reading experience is enhanced with an actual playlist of titles evoked by Nin, while her use of musicality through metaphor keeps readers' ears tuned in to a written rhythm. What the following extracts will prove is that there is a constant crossing back and forth in Nin's work from text to music, oral rhythm and textual rhythm. Furthermore, the evolution in Nin's own writing and philosopy is reflected by the musical works and styles she cites, as she transitions from classical works to jazz. 
2 Even the genre of The Cities of the Interior collection reflects the musical structure of movements within a score of themes and variations. As a roman-fleuve work, the characters and storylines from one volume spill over into the others, constructing the psychological architecture of the characters by evoking their psyches, their intimate thoughts, and their withdrawal from the outside world (Meral 244). These volumes may be read individually, in practically any order, which means that the chronology is equally fluid. Sometimes, when reading The Cities of the Interior, phrases or complete passages seem to be taken verbatim from Nin's diaries. Analysis of the published diaries concludes that they, too, are fictional productions. Jean Meral explains: "Il ne faut pas croire, d'ailleurs, que le journal permette, pour faciliter l'analyse, de placer en parallèle la vie et l'œuvre de l'auteur. Entreprise littéraire autonome, il n'est en aucun cas une autobiographie, d'autant plus que, expurgé pour des raisons personnelles et juridiques dans sa forme publiée, il laisse de larges zones d'ombre ou d'incertitude" (Meral 239). To move forward in analyzing Nin's works, it is therefore essential to understand the relationship between the diaries and the fictional novellas, understanding that both are crafted works. From a more technical perspective, in Orchestrating Reality: Notes on Musical Form in the Writings of Anais Nin and Henry Miller, Karl Orend explains the differences between the autobiographical and the diaries by using chronology, pointing out that while based on earlier events, the diaries are "rewritten texts dating mainly from the 1950s and 1960s" (Orend 19). The Cities of the Interior is further characterized by Nin's own poetic process and figurative language. This style has been referred to by Nin herself as "the language of emotions," "the language of the womb," "music of the womb," and "vaginal song" (Spencer 55). It is in one of her two erotic works, Delta of Venus, that we hear this particular female voice:

[...] the voice of a woman began what seemed at first to be a song, and then turned out to be another sort of vocalizing, the vocalizing of the exotic bird finally caught in the mating season. [...] The woman's vocalizing became clearer, firmer, rising in harmony with her pleasure [...]. It was so explicit, so female, betraying women's soft cushion of love pierced by the male, uttering with each thrust a little cry of the ecstatic wound [...] this vaginal song. (Nin 1969, 115)

3 An expression that begins as a recognizable song devolves into an exotic sound that is itself eroticized by the reference to mating season. This vocalizing is affirmed as its subject experiences sexual pleasure, and it is "so female," aligning the sound with the character's gender. This passage is one example of how the experience of female sexual pleasure and its translation into an audible expression are inseparable when it comes to the sonority of Nin's sensuous writing. This focus on women's sexuality is a key element to her corpus. Critic Sharon Spencer explains:

The phrase "music of the womb" unites the two most original-and most basiccharacteristics of Anaïs Nin's body of fiction. Her writing is "musical" because it achieves its experiential impact through carefully constructed lyrical passages built up of textured, interrelated images; it is a "music of the womb" because it became (in the late 1930s) a consciously articulated expression of woman's experience, aspirations, and values. Nin wanted to endow words with flesh and blood, so to speak, to instill an inner dynamism, or élan vital, to demonstrate the value of sensitivity, empathy, compassion, eroticism, sensual pleasure and love of all kinds, as well as an appreciation of the arts. (Spencer 55-56)

In this way, many messages about female anatomy, female sexuality, woman's experience, and woman's reaction to the arts are wrapped up in the particular "musical" style of Nin. She herself aligns her approach to writing with musical composition: "[...] to put it in 
terms of music, I hear a melody, a few bars, and on this I improvise until the theme is fully developed and complete [...] I have no ready-made plot, but I do have a theme" (Nin 1968, 80). Again, theme and variation is both a metaphor about her writing and also a structural approach to her writing. Nin's alignment of musical composition with literary composition is further reinforced by the representation of musicians in her work, the use of musical metaphors evoking a soundscape throughout the text, and references to César Franck and Claude Debussy that augment the polysensorial experience for readers as they traverse the cities of the interior.

\section{Anaïs Nin's Musicians}

5 Anaïs Nin grew up in a family of musicians-her mom was a singer and her father a pianist and composer, as her brother would later become. The entire existence of the family hinged on Joaquin Nin's professional musical career, and the frequent moves and instability of the family are a direct result of that (Bair 77). Orend suggests that this musical upbringing, often fraught with severe family disagreements, would traumatize Nin and push her to seek later both personal and professional "harmony". He further states:

She sought to replace discord with music (her symbol of peace and reconciliation, leading to dance or intimacy). [...] Anaïs often chose for her characters artists, musicians and writers, because these were the people she had been surrounded by all her life. She also chose them because they "had chosen to live by their impulses rather than those who had to fit themselves into accepted social patterns." (Orend 18)

Not only did she grow up with musicians, she also attributed them with credibility for following their artistic impulses.

Despite her admiration for musicians and her quest for harmony, one problem was that Anaïs herself was not as musically inclined as the others. Biographer Deirdre Bair explains: "Anaïs learned solfege for several years in Brussels, but she lacked interest as well as talent: practicing was 'too difficult' or she was 'too weak' or 'too tired.' She had a pleasant voice, but not one of professional caliber. In a house filled with music and dominated both professionally and financially by it, she was the odd person out" (Bair 16). Orend posits that Nin compensated for her lack of musical talent and her failed dancing career by building her fiction on the frameworks and structures of music and dance (Orend 7). Given the importance music and musicians held for Nin from childhood, it is no surprise that these real, live musicians would later be recycled into characters of her fiction, in addition to "generic" or "stereotypical" musician characters.

It is the story of Djuna ${ }^{1}$, the dancer, which is told in Children of the Albatross. Set in Paris, the café setting will be used as the universal backdrop for the gathering of all types of artists. Musicians will be included in this creative melting pot:

And so in the café, with one franc for a glass of wine and even less for coffee, you could hear stories from the Pampas, share in African voodoo secrets, read the pages of a book being written, listen to a poem, to the death rattles of an aristocrat, the life story of a revolutionary. You could hear the hummed theme of a symphony, watch the fingers of a jazz drummer drumming on the table, accept an invitation from a painter who would take you to the Zoo to watch the serpents eat their daily ration of white mice, consult a secretive Hindu on his explorations of occult streets, or meet an explorer who would take you on his sailboat around the world. (Nin 1947, 72-73, emphasis added) 

synergy in this one place. It is also a space that reflects the artistic approach of Nin and Miller: "Anaïs Nin and Henry Miller grew up in an age in which collaboration between writers, musicians and artists was at a peak. [...] Both Henry and Anaïs tried to use the techniques they observed in writing, painting, theatre, ballet, musical composition and jazz improvisation to enrich their writing. They learned to see the world and its people with the eyes of not only a writer, but also an artist and a musician" (Orend 33). In this way, the description of the scene in Children reflects the lived artistic approach of its author. What is unique about the music mentioned, however, is that it is not current contemporary French airs or political anthems. Rather, at the café, it is the theme of a symphony and jazz rhythms that may be heard-two contrasting examples that reflect both classical academic works and the more modern, popular jazz. Nin's musical references will often circulate between these two poles.

Djuna's story continues in The Four-chambered Heart. This phase of the narrative continues in Paris, and now the musician character is very precise: Rango is a guitar-playing gypsy, and the text opens with his description:

The guitar distilled its music. Rango played it with the warm copper color of his skin, with the charcoal pupil of his eyes, with the underbrush thickness of his eyebrows, pouring into the honey-colored box the flavors of the open road on which he lived his gypsy life: thyme, rosemary, oregano, marjoram, and sage. Pouring into the resonant box the sensual swing of his hammock hung across the gypsy cart and the dreams born on his mattress of black horsehair. (Nin 1950, 8)

This portrait appeals to our senses-we see many colors (copper, charcoal, honey-colored) and we taste many flavors (honey, thyme, rosemary, oregano, marjoram, and sage). Textures are present with the "underbrush thickness" and the "horsehair" mattress. But, more importantly, Nin puts together the musician's sounds with his story-the sounds reflect his "gypsy life"-and the "sensual swing" mimics the hammock swinging in his gypsy cart. It is important for the character painting the portrait of the musician to believe he is a gypsy. In this instance, the sound of the music played by the musician is the setting for his character creation. Rango is one example of the seductive musician present in the Nin corpus. Brought up in a musical family and immersed in an artistic context, music and musicians were significant to Anaïs, who did not hesitate to write what she knew about them. They represent one layer of sonority in her works, but she also employed musical metaphors as part of her writing rhythm.

\section{Musical Metaphors}

11 As an evident link to the musicality Nin evokes, dancing is equally present in The Cities of the Interior. The narrative strategy of using music and dancing to transport characters to a different place, whether physical or figurative, is repeated throughout this corpus. Like Djuna, characters are sometimes professional dancers or engage in dancing with other characters. In Children of the Albatross, it is an internal sound that causes Djuna to dance her way to a nostalgic location:

Lifted and impelled by an inner rhythm, with a music box playing inside her head, her foot lifted from drabness and immobility, from the swamps and miasmas of poverty, carried her across continents and oceans, depositing her on the cobblestones of a Paris square on the day of the Fair, among shimmering colored 
tents, the flags of pleasure at full mast, the merry-go-rounds turning like dervish

dancers. (Nin 1947, 5)

When readers come across the "music box," a happy, distant tinkling sound is evoked. Djuna's inner rhythm carries both her and the readers to a "happy place," where colors and twirling motions contrast "drabness" and "immobility". The merry-go-round communicates not only motion but also a happy music associated with childhood, echoing the tinkling music box. In true expatriate literary tradition, the character is transported to Paris. While the music evoked is not specified by title, it is one to which readers may relate. Specific elements of the scene (the music box, the fair, and the merrygo-round) produce a sense of happiness and harmony, perhaps the harmony for which Nin was so nostalgic. Furthermore, the notion of "pleasure," represented through flags at "full mast" is ever-present.

Later on in the same volume, music and dancing will be yet again implied together. The combination is used to describe the relationship between Paul and Djuna:

The movements of the symphony and her movements had been always like Paul's, a ballet of oscillations, peripheral entrances and exits, figures designed to become invisible in moments of danger, pirouetting with all the winged knowledge of birds to avoid collision with violence and severity. Together they had taken leaps into the air to avoid obstacles. (Nin 1947, 70)

14 Here, musical movements and physical movements mirror each other to communicate across the senses how two characters move through the narrative "avoiding obstacles". We can note that their physical movements, like the musical ones, enter, exit, twist and turn, grow and swell, yet fall short of a climax in order to avoid collision with obstacles. Readers can image both repetitive movements and repetitive sounds-like those we will hear in César Franck's Symphony and Debussy's Isle Joyeuse discussed below.

The use of musical metaphors is not unique to Nin's cityscapes; if the previous passages have been more allegro, there is a distinct slowing down to largo in Seduction of the Minotaur. In this piece, the slower musical rhythm is used as a structural metaphor to indicate the tempo of the setting.

It was not only the music from the guitars but the music of the body that Lillian heard-a continuous rhythm of life. There was a rhythm in the way the women lifted the water jugs onto their heads, and walked balancing them. There was a rhythm in the way the shepherds walked after their lambs and their cows. It was not just the climate, but the people themselves who exuded a more ardent life. (Nin 1950, 14)

17 This passage sets the percussion-like soundtrack of several rhythms playing simultaneously: the guitar, the body, the cycles of life, and the steps of the shepherds' feet and the animals' hooves. Despite the absence of bells in the passage, readers almost hear a type of "clink-clink" as the animals move along. The laid-back rural setting is captured through the subtle punctuation of this easy-going rhythm-and once again, musical rhythm is mentioned together with the music of the body. As Diane RichardAllerdyce points out:

Numerous passages show a connection between the visual and the musical arts, on one hand, and a perceptual reality rooted in the body but apprehended in language, on the other. Linking rhythm to the visual realm, Seduction provides comment upon Modernist painting in terms of both physical and psychological landscape and its associative images. (Richard-Allerdyce 131) 

relies not only on its foreign setting (Mexico), but also on the soundscape to lead readers towards the final harmony of the work. These examples demonstrate that Nin relies heavily on evoking sounds in her texts. Dancing and musical metaphors have been used to multiply or transform characters' locations, to demonstrate the relationship between characters, and to give a sensual experience of place. The interweaving of text and music amplifies the richness of the texture of the reading experience. Yet, we can take Nin's creation of a soundtrack for her readers one step further by analyzing what exactly it is that specific musical references bring to passages in the text.

\section{Franck, Debussy, and Jazz in The Cities of the Interior}

19 Although there is divergence in their composition styles, it is not illogical for Nin to cite Franck and Debussy together-after all, Debussy audited Franck's organ class for several months in 1880-81 (Centre de documentation Claude Debussy np). However, what may surprise informed readers is Nin's choice to cite Franck's Symphony in D Minor (1888), as this piece is not the most popular in Franck's repertoire; notably, it was considered a failure at its premiere (Lieberman np). Vincent d'Indy directed the first performance, which was held on February 17, 1889, in Paris (Huscher np). D'Indy was a disciple of Franck's, and as founder and director of the Schola Cantorum, Joaquin Nin knew him (Blair 15). We can therefore establish a direct family link between Anaïs Nin's past and Franck's symphony.

Analyses of the piece, such as those provided by Anthonio, Huscher and Lieberman, evoke repetition and the cyclical apparition of themes during the 41-minute symphony. In fact, when reading about the score, we could be reading about Nin's roman-fleuve: "[...] he was also impressed with the issue of cyclic composition [...]. It is a method of composition in which themes are developed from short melodic phrases, then manipulated and expanded throughout the whole composition to bind the work together" (Anthonio np) This description reflects Nin's own words about her approach to writing seen earlier. Both musical composer and literary author are working through the same themes that are eventually brought together.

In a first citation from Children of the Albatross, Nin simply posits the symphony as a type of background music: "For one moment, sitting there with Paul, listening to the Symphony in D Minor of César Franck, through his eyes she [Djuna] was allowed behind the mirror into a smaller silk-lined house of faith" (Nin 1947, 47). In this instance, we as readers cannot really imagine an echoing of meaning between the text and the music-we just know what the characters are listening to at the time-Symphony in D Minor is on the playlist. About twenty pages later in the same volume, however, the allusion to the symphony seems to be much more involved, and the ebbing and flowing of music contextualizes the relationship between the characters:

They were both listening to César Franck's Symphony in D Minor.

And then the conflicted selves in Djuna fused into one mood as they do at such musical crossroads.

The theme of the symphony was gentleness.

She had first heard it at the age of sixteen one rainy afternoon and associated it with her first experience of love, of a love without climax which she had known with Michael. She had interwoven this music with her first concept of the nature of 
love as one of ultimate, infinite gentleness.

In César Franck's symphony there was immediate exaltation, dissolution in feeling and the evasion of violence. Over and over again in this musical ascension of emotion, the stairway of fever was climbed and deserted before one reached explosion.

An obsessional return to minor themes, creating an endless tranquility, and at sixteen she had believed that the experience of love was utterly contained in this gently flowing drug, in the delicate spirals, cadences, and undulations of this music. César Franck came bringing a message of softness and trust, accompanying Paul's gestures and attitudes, and for this she trusted him, a passion without the storms of destruction.

She had wanted such nebulous landscapes, such vertiginous spirals without explosions: the drug.

Listening to the symphony flowing and yet not flowing (for there was a static groove in which it remained imprisoned, so similar to the walled-in room of her house, containing a mystery of stillness), Djuna saw the Obelisk in the Place de la Concorde, the arrow of stone placed at the center of a gracefully turbulent square, summating gardens, fountains and rivers of automobiles. One pointed dart of stone to pierce the night, the fog, the rain, the sun, aiming faultlessly into the clouds. (Nin 1947, 65-66)

The symphony brings harmony to the multiple facets of Djuna's character, and it is considered a "musical crossroads"-which helps us to audibly bridge the crossings between music and text. The theme of gentleness is a reference to Djuna's relationship to Michael who is homosexual (and who therefore never penetrates her-as indicated by "without climax"), but this same gentleness is heard in the Symphony's second movement, which surprisingly begins with an English horn solo, so gentle that the volume has to be adjusted to hear it (Lieberman np). The next sentences describe the rising and falling of the musical themes that do not explode into a climax. When we read "an obsessional return to minor themes," we are not sure if the narration is referring to Franck's piece or Djuna's relationship to Michael. In Petit guide de l'auditeur de musique : musique symbolique et religieuse, Chantavoine and Rostand equally address the rising and falling back to themes without reaching a climax:

Tel est l'accent qui frappe dans le premier mouvement de la Symphonie en ré mineur, où se partagent d'une façon si émouvante l'inquiétude et la décision, bref, la peine qu'éprouve l'homme à se dégager de lui-même. [...] C'est par là que, symphonie classique par sa forme, la symphonie de Franck est, par son esprit, un poème romantique. (Chantavoine and Rostand 118)

They conclude that Franck's musical piece is much like a romantic poem-just like Nin's prose poetry here functions as a symphony. Nin reinforces this tension of rising and falling musical themes and physical sensations by the terms "endless tranquility," which implies both frustration and calm. Finally, the passage closes on yet another example of how sound carries characters to distant places that can be seen in the mind's eye-here again it is Paris. Symphony in D Minor is synonymous with Place de la Concorde, and its phallic Obelisk. When Nin writes about pointed stones and "piercing," she is evoking the sexual act that never took place within the gentleness between Djuna and Michael. As we draw conclusions about what Franck's symphony brings to Nin's literary passage, we can note that the music and the text present parallel sentiments. Betina Knapp takes the analysis one step further, concluding that the music acts as a companion to Djuna:

Franck's emphasis on theme, exposition, tone timber, and serial pattern is an expression of the eternal quality of human pain, as well as joy. [...] It is through Franck's symphony that Djuna begins to understand her emotions as these are replicated in harmonies, polyphonies, and the structured order of the musical 
phrases. [...] Music symbolizes an intermediate zone between the material and the undifferentiated realm. Music expresses the fluidity of her feelings and generates love [...]. Like a companion, music helps Djuna through her ordeal [...]. (Knapp 120)

Not the most admired of Franck's works, this anti-climatic symphony fits Nin's use of providing her character with a surging and lulling expression by which to process her own feelings. If music is a companion to Djuna, this music also accompanies readers. These passages have revealed that the musical styles used by Franck, such as repetition and cyclical themes, a surging and falling motion that never arrives at a full climax, and a tone of gentleness, are reflected in Nin's own writing style, and they are important tools in building the city of her interior.

From this somber Franck symphony, Nin will jump to Debussy's lively, bright Isle Joyeuse (1904). Both pieces seem to be evoked for the way in which they reinforce Nin's metaphors for sexuality, just as both pieces held sentimental value for her. Helen Tookey attests to the numerous comments regarding Nin's fascination with Debussy and his music. By citing a precise passage of her Diary, Tookey proves Nin's preference for this "modern" approach, further indicating how she wished to integrate it in her own writing:

I didn't care for Beethoven's Pastoral or Berlioz's Fantastique. Both too literal and descriptive. Prefer suggestive music like Debussy's and Falla's-something more subtle, more indirect. [...] I would give twenty years of my precious life to be able to write as Debussy composed, to be able to give that profound, intangible, wordless sensation. [...] [Music] goes directly through our senses, whereas only a certain kind of writing will go through our senses, and it is this penetration I seek. (17 April 1931, Early Diary, IV, 417-418 cited in Tookey 137-138)

Nin associates Debussy's composition with its more sensuous aspects-evoking physical sensations and the senses. She is seeking a penetrative writing that reflects the sexual desire of penetration on the part of her characters. In addition to her own preference for the composer, it was an interest she shared with Henry Miller. She writes in her diary that Miller was listening to Debussy and wrote to her while doing so: "More letters from Henry, parts of his book as he writes it, quotations, notes while listening to Debussy and Ravel, on the back of menus of small restaurants in shabby quarters. A torrent of realism" (Nin 1966, 55). The two authors were able to share the listening experience even through their written correspondence.

To understand the importance of the Debussy work, we should consider its genesis: he completed the five-minute piece on the British island of Jersey during a romantic get away with his lover. Some critics posit that it was inspired by Watteau's painting, L'Embarquement pour Cythère, in which two lovers head to the island (Moore np). The painting, for its part, is based on the last lines of the comedy entitled Les Trois Cousins, written by Dancourt in 1702, which instruct:

Venez à l'île de Cythère

En pèlerinage avec nous

Jeune fille n'en revient guère

Ou sans amant ou sans époux (Picard et Peyrot 531) 


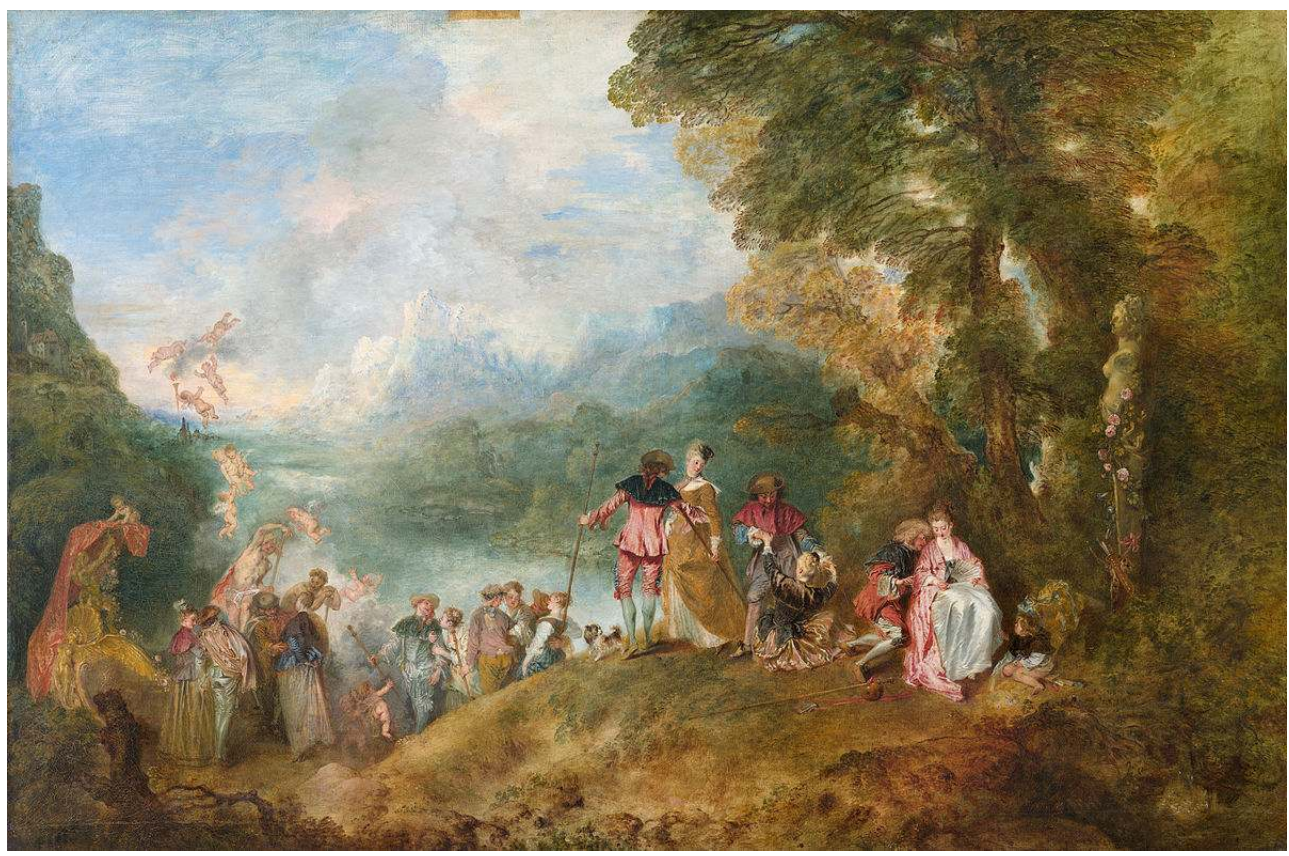

Jean-Antoine Watteau, L'Embarquement pour Cythère (1717), huile sur toile, 129x194cm, Musée du Louvre, Wikimedia Commons joy to represent the presence or absence of sex and seduction. In her article, "De la partition au texte: Anaïs Nin ou le tombeau de Debussy," Nathalie Vincent also speaks to the presence and symbolism of the piece in Nin's corpus: "D'un point de vue structurel tout d'abord, la répétition du motif que constitue l'Isle Joyeuse confère bien souvent au texte une pulsation interne qui semble régie par les élans de l'imaginaire, par les assauts de ce désir de plénitude qui taraude les héroïnes" (Vincent 316). Functioning as a metronome, Debussy's Isle Joyeuse keeps the text's rhythm and that of the female characters in time. Proceeding in chronological order, the citation is intertextual from one volume to the next. Returning to Children of the Albatross, like Franck's, Debussy's piece is used in reference to the lack of penetrative sexuality between Djuna and Michael and even Michael and Donald. With its frenzied beat, the piece is often referred to in the context of its rhythm. Characters dance to it: "To the tune of Debussy's Isle Joyeuse, they gracefully made all the steps which lead to no possession" (Nin 1947, 33). Here, the sexuality halters because the male character is homosexual-and whether it be the male and female character, or the two male characters, they only dance, rather than make love. 
As una's story continues in The Four-chambered Heart, the joyous island representing happiness will also wash away with sexual disappointment. At the moment she discovers that Rango the gypsy guitar player is in fact not a gypsy, Djuna's potential island of joy washes into the sea: "He did not know that she had just lost sight of an island of joy. The image of an island of joy evoked by his guitar had vanished. In walking toward a mirage of freedom, she had entered a black forest, the black forest of his eyes darkening when he said: 'Zora is very ill'" (Nin 1950, 11). The music produced by Rango's guitar created an island of sexual fantasy. But, now that he has admitted he is married to an ill woman, it ruins Djuna's fantasy of him as gypsy lover-instead, his music offers a black forest in which the way out is obscured.

The sexual promise of the Isle Joyeuse climaxes in A Spy in the House of Love. The Debussy piece functions first as an aphrodisiac, transporting the character Sabina's sexual self beyond her reality:

The image of the ship's cracking, restless bones arrived on the waves of Debussy's Ile Joyeuse which wove around her all the mists and dissolutions of remote islands. The model notes arrived charged like a caravan of spices, gold mitres, ciboriums [sic] and chalices bearing messages of delight setting the honey flowing between the thighs, erecting sensual minarets on men's bodies as they lay flat on the sand. [...] By wishing to be there where it was more marvellous she made the near, the palpable seem like obstruction, a delay to the more luminous life awaiting her, the incandescent personages kept waiting. [...] The present [...] was murdered by the insistent, whispering interfering dream, a compass pointing to mirages flowing in the music of Debussy like an endless beckoning, alluring, its voices growing fainter if she did not listen with her whole being. (Nin 1954, 45)

31 Immediately, the sounds of the music are equated with the island atmosphere. The audible "model notes" paint visual images through synesthesia, which trigger both female and male anatomies, "setting the honey flowing" and "erecting minarets." This extract demonstrates yet again that the music transports the character to a happier place than that of the present. Benjamin Franklin V has suggested that Sabina "returns to reality from her dream before she is trapped within it, and from it she has gained the sustenance to live another week with her husband who does not know her and who forces her to be what she is not" (Franklin V 117). Again, "like a companion," the music helps the character through her "ordeal," which contrasts greatly from her ideal situation. Although this passage does not portray a sexual encounter between the two characters physically present in the scene, there is the suggestion of potential sex acts to come in the dreamscape.

Sexual climax and musical climax finally coincide later in the novella through the rhythm of the musical piece. A citation from the novella employs a repetition of the word "joyous," which, in the global context of The Cities of the Interior, refers back to the Debussy piece. As Nathalie Vincent points out, Isle Joyeuse has become amalgamated into a concept throughout the series of novellas:

C'est le cas de cette Isle Joyeuse qui finit par être amalgamée, sans guillemets et sans capitales, dans la trame du monologue, dans un processus fantasmatique qui génère ses propres images, nées de l'incorporation intime de mythes vénérés. Ce processus d'intégration individuelle, de véritable anamorphose du topos originel, marque en tout cas l'étape ultime de cette relation triangulaire qui s'établit entre Anaïs Nin, Debussy et les poètes-nombreux-qui ont inspiré ce dernier: le texte littéraire fait ainsi retour au texte littéraire après avoir transité par la voie musicale et avoir glané au passage une plus-value substantielle. (Vincent 317)

Polysèmes, 16 | 2016 

example of crossing back and forth between text and music. In the context of Nin's works, Isle Joyeuse is at the same time the famous work by Debussy, but also the idea of a distant romantic location and the experience of joy, which here is equated to female orgasm. This jumbling together of the "fantasmatic process" is demonstrated as a female character speaks of the "[...] only one ritual, a joyous, joyous, joyous, joyous impaling of woman on man's sensual mast" (Nin 1954, 38). Readers cannot ignore the emphasis, on the part of Nin, of the fulfillment of woman's sexuality in this statement. Not only is the Debussy piece referred to indirectly, but also, the sexual and romantic prospects of the joyful island are definitively obtained.

Ultimately, these extracts demonstrate how Nin layers elements from Debussy's music over into her own writing: Isle Joyeuse brings a sense of modernity, a bright and joyful tone, and the concept of transporting listeners and readers to a happier place. Across the three volumes, the melody of Isle Joyeuse plays during a range of sexual experiences, from failed intercourse to orgasm. The poetic, rhythmic description of intercourse, from a female experience, is intertextual to the ensemble of Isle Joyeuse imagery. Furthermore, Nin evokes Isle Joyeuse to shift from academic music to the improvisation genre. The rhythm of Debussy's Isle Joyeuse is transposed onto the "drumming" of the character Mambo, which is sexually coded: "from Debussy's Ile Joyeuse to Mambo's drumming from Ile Joyeuse" (Nin 1954, 45). Knapp reads Nin's emphasis on the drumming rhythm here as moving Sabina from the classical musical world to jazz culture: "gone is the guilt-filled puritanical world. [...] Her Mambo seems to encompass all the Louis Armstrongs, Buddu Boldens, Duke Ellingtons, Fats Wallers. Although an individual, Mambo is an archetypal figure, a black divinity whose powerful harmonies and cacophonies, beats and syncopations, capture her entire being" (Knapp 138). Mambo is racially and sexually symbolic in this passage-it is through his character and his rhythms that the "jazz" mode may be reached. The specific musical score has now given way to the jazz genre, which critics such as Tookey regard as a marker in the maturation of Nin and her shift from locating herself within a European tradition to an American one: "Jazz is important for Nin in several respects. As a quintessentially American art form, it represents a linkone of the few links Nin can see-between the American context and the French avantgarde tradition" (Tookey 139). Nin adopts and adapts jazz music in her writing as a bridge between two cultures and as a way to modernize her characters.

As these selected extracts have shown, Anaïs Nin's roman-fleuve offers a case study when considering the interdisciplinary crossings between text and music. The overwhelming presence of musicians, musical vocabulary, and specific references to musical works creates a soundtrack for readers to listen to the text as they read it. Moreover, the evocation of Symphony in D Minor and Isle Joyeuse invites readers to listen more closely in order to discover the stylistic elements that overflow from the pieces of music into the storyline. We may conclude that Nin had a personal attachment to both pieces, but that she also used the symbolism of each to reinforce scenes from her own text. Symphony in $D$ Minor rises and falls, maintaining a gentleness that does not climax, like Djuna's relationship to Michael. Whether consummated or not, Isle Joyeuse is about a romantic euphoria, either from a real or mythological island get away, where woman can "joyfully" impale herself on "man's mast." Both pieces of music are used to help the female characters cope with their less-than-ideal realities. As a more modern alternative to the classical pieces, jazz rhythms are equally introduced as a means of relieving female sexual 
frustration. In this way, Nin has included some of her favorite pieces of music as she writes through a range of female sexual experiences, seeking a balance or a harmony between women and men, American and European traditions, and musical and textual media, elements used to build The Cities of the Interior.

\section{BIBLIOGRAPHY}

Anthonio, Michael. “An Inktroduction: César Franck-Symphony in D Minor.” The Flying Inkpot. 2000. http://inkpot.com/classical/francksymphony.html

Bair, Deirdre. Anaïs Nin: A Biography. New York: Putnam, 1995.

Benstock, Shari. Women of the Left Bank. Austin: U of Texas P, 1986.

Centre de documentation Claude Debussy. "Formative Years." 2007. http://www.debussy.fr/ encd/bio/bio1_62-82.php

Chantavoine, Jean et Claude Rostand. Petit guide de l'auditeur de musique : musique symbolique et religieuse. Paris: Éditions le Bon Plaisir, 1958.

Debussy, Claude. Isle Joyeuse. Maurizio Pollini. ( 1999 by Deutsche Grammophon. B00002R2SU. Compact Disc.

Franklin V, Benjamin and Duane Schneider. Anaïs Nin: An Introduction. Athens: Ohio UP, 1982.

Franck, César. Symphony In D Minor/D’Indy: Symphonie sur un chant montagnard ("Symphonie cévénole"). Charles Dutoit and Jean-Yves Thibaudet and Orchestre Symphonique de Montréal. (c 1991, 2006, 2010 by Decca Music Group Limited. B003SX5IBC. Compact Disc.

Huscher, Phillip. “César Franck-Symphony in D Minor." Chicago Symphony Orchestra Program Notes.

http://cso.org/uploadedfiles/1_tickets_and_events/program_notes/

programnotes_franck_symphonyd.pdf

Jason, Phillip (ed.). The Critical Response to Anais Nin. Westport, Connecticut: Greenwood Press, 1996.

Knapp, Betina L. Anaïs Nin. New York: Frederick Ungar Publishing Co., 1978.

Lieberman, David Isadore. "Symphony in D minor (1886-88)." 1999. http://

www.loudounsymphony.org/notes/franck-symphony

Meral, Jean. Paris dans la littérature américaine. Paris: Éditions CNRS, 1983.

Moore, Diane Enget. "Debussy in Jersey: The Centenary, 1904-2004." LitArt-Publishers of Literary Pamphlets. http://www.litart.co.uk/isle.htm

Nin, Anaïs. The Diary of Anaïs Nin, volume 1: 1931-1934. New York: Swallow Press, 1966.

Nin, Anaïs. Ladders to Fire (1946). Athens: Swallow Press/Ohio UP, 1959.

Nin, Anaïs. Children of the Albatross (1947). Athens: Swallow Press/Ohio UP, 1959.

Nin, Anaïs. A Spy in the House of Love (1954). Chicago: Swallow Press, 1959. 
Nin, Anaïs. Seduction of the Minotaur (1950). Denver: Swallow Press, 1961.

Nin, Anaïs. The Four-Chambered Heart (1950). Denver: Swallow Press, 1966.

Nin, Anaiis. The Novel of the Future. Athens: Swallow Press/Ohio UP, 1968.

Nin, Anaïs. Delta of Venus. Athens: Swallow Press/Ohio UP, 1969.

Nin, Anaïs. A Woman Speaks. Eveyln J. Hinz (ed.). Chicago: Swallow Press, 1975.

Orend, Karl. Orchestrating Reality: Notes on Musical Form in the Writings of Anaïs Nin and Henry Miller. Paris: Alyscamp Press, 2007.

Picard, L.B. et J. Peyrot. Répertoire de théâtre français, Volume 21. Paris: F.A. Duprat, 1826. E-book.

Richard-Allerdyce, Diane. Anaïs Nin and the Remaking of Self: Gender, Modernism, and Narrative Identity. Delkab: Northern Illinois UP, 1998.

Spencer, Sharon. "The Music of the Womb: Anaïs Nin's 'Feminine Writing." The Critical Response to Anaïs Nin. Westport, Connecticut: Greenwood Press, 1996, 55-75.

Tookey, Helen. Anaïs Nin, Fictionality and Femininity: Playing a Thousand Roles. Oxford: Oxford UP, 2003.

Vincent, Nathalie. "De la partition au texte: Anaïs Nin ou le tombeau de Debussy." Anglophonia: French Journal of English Studies 11 (2002): 311-318.

\section{NOTES}

1. While the reference to Djuna Barnes seems obvious, as pointed out by Shari Benstock (429) and Jean Meral (236), Nin herself also claims finding it in a book of names (Nin 1975, 231).

\section{ABSTRACTS}

Anaïs Nin's roman-fleuve, The Cities of the Interior, offers a case study when considering the interdisciplinary crossings between text and music. The overwhelming presence of musicians, musical vocabulary, and specific references to musical works creates a soundtrack for readers to listen to the text as they read it. Furthermore, the evocation of César Frank's Symphony in D Minor and Claude Debussy's Isle Joyeuse begs readers to ask what extra meanings these pieces of music bring to the storyline. We may conclude that Nin had a personal attachment to both pieces, but that she also used the symbolism of each to reinforce scenes from her own text. Symphony in $D$ Minor rises and falls, maintaining a gentleness that does not climax, like Djuna's relationship to Michael. Isle Joyeuse is about a romantic euphoria, either from a real or mythological island getaway, where woman can « joyfully » impale herself on « man's mast. » Readers are invited to cross the intertextual bridge between Nin's text and the referenced musical context in order to enter The Cities of the Interior.

The Cities of the Interior, roman-fleuve d'Anaïs Nin, offre un cas d'étude de l'intertextualité entre musique et littérature, et de la "traversée » entre ces deux arts. La présence de personnages 
musiciens, le champ lexical de la musique, et les références à des œuvres musicales contribuent à créer une bande-son audible lors de la lecture. Les évocations de la Symphonie en ré mineur de César Frank et de l'Isle Joyeuse de Claude Debussy poussent également les lecteurs à s'interroger sur le sens que ces références ajoutent à la trame du roman. Son histoire personnelle révèle que Nin avait un attachement aux deux morceaux, mais nous concluons également qu'elle emploie le symbolisme de chacun pour renforcer les scènes et les interactions entre les personnages dans son propre texte. La mélodie de la Symphonie en ré mineur reflète la dynamique de la relation entre Djuna et Michael. L'histoire et la mélodie de l'Isle Joyeuse représentent une euphorie romantique, qui vient d'un déplacement réel ou imaginaire vers une île, où une femme aurait l'occasion de s'empaler "gaiement" sur un "mât viril". Les lecteurs sont invités à opérer cette traversée entre le texte de Nin et les morceaux évoqués pour entrer dans la ville intérieure qui constitue l'ensemble des histoires rassemblées dans The Cities of the Interior.

\section{INDEX}

Mots-clés: bande-son, écriture symphonique, métaphore musicale, texte/musique oeuvrecitee Cities of the Interior (The), Isle Joyeuse

Keywords: soundtrack, symphonic writing, musical metaphor, text/music

\section{AUTHORS}

\section{AMY D. WELLS}

Amy D. Wells est maître de conférences en anglais à l'université de Caen Normandie, au département de Langues Étrangères Appliquées. Avec sa thèse, intitulée Gender and Geography: A Geocritical Approach to Left Bank Women's Writing 1903-1941, elle a entrepris l'analyse des ouvrages féminins des Américaines vivant à Paris, dont Anaïs Nin fait partie. Parmi ses publications récentes, les articles « Le Sexe Partout : le Havre vu par Henry Miller dans Tropic of Cancer» (2014), « Rewriting as Political Revendication: Djuna Barnes's Feminist Twist on Chaucer » (2015), « Sugary Celebrations and Culinary Activism: Sugar, Cooking, and Entertaining During World War I » (2015) et « A City Girl's Pastoral Playground: A Geocritical Approach to Gendered Arcadia in Nin's Cities of the Interior » (2015). Amy Wells a également traduit The Plausible World: A Geocritical Approach to Space, Place and Maps de Bertrand Westphal, paru chez Palgrave en 2013. 